DOI: 10.31866/2616-7581.4.1.2021.233342

UDC 785.1:78.071.1(479.24)Ramazanov

\title{
SYMPHONIC CREATIVE ACTIVITY OF RUFAT RAMAZANOV
}

\section{Mekhpara Rzaieva}

PhD in Art Studies; Senior Research Fellow;

ORCID: 0000-0002-0962-5416; e-mail: mexpara.rzayeva@mail.ru

Baku Music Academy named after U. Hajibeyli, Baku, Azerbaijan

\begin{abstract}
The article analyzes several works related to the symphonic work of Rufat Ramazanov, a middle-aged representative of the modern Azerbaijani school of composition. The article also examines Ramazanov's symphonic works against the background of the development of Azerbaijani music culture and examines his symphonic works in terms of genre diversity. Also, the article considers the characteristics of music and harmonic language in the symphonic works of the composer, the methods of using orchestration. The article emphasizes the unique stylistic features of Rufat Ramazanov's symphonic works, their connection with folk art, and his tendency to modernize within the traditions.
\end{abstract}

The purpose of the research is to analyze certain symphonic works of Rufat Ramazanov and to study the individual stylistic features of the composer. The main touches are the emergence of the characteristic features of the composer's symphonic work and the discovery of its connection with modern Azerbaijani music culture. The basis of the research is the involvement in detailed scientific research of several valuable symphonic works of R. Ramazanov, a worthy representative of the modern generation of Azerbaijani composers, which have not been subjected to scientific and theoretical analysis. From this point of view, the research is based on the method of complex theoretical analysis.

The research methodology is based on music-analytical, theoretical, and historical analysis. It was noted that the composer's work has undergone stylistic changes in the process of development, and modern technical methods have uniquely manifested themselves. At the same time, based on the scientific-theoretical principles and research of Azerbaijani and foreign musicologists, the article forms the methodological basis.

The scientific novelty of the research is that for the first time as special research work, the article is devoted to the symphonic work of R. Ramazanov, a representative of the modern school of the composition of Azerbaijan, and the study of general creative features associated with it. The presented article for the first time scientifically analyzes the symphonic works of R. Ramazanov, which are important in his work but have not been studied so far.

Conclusions. A comprehensive analysis of Ramazanov's symphonic works in the presented article allows one to draw important conclusions about the features of the composer's creative style. It was noted that the richness and deep content of the musical language of the bright and 
individual symphonic works created by Ramazanov, one of the modern Azerbaijani composers distinguished by his original creative style, in various years of his creative life are important in our national music art.

It was noted that the composer's insistence and seriousness towards himself are also felt like his works. From this point of view, Ramazanov's symphonic music and modern writing techniques with rich images were chosen from his contemporaries and recognized in our music society and were welcomed not only in his homeland but also far beyond its borders. It should be noted that several of Ramazanov's works have been successfully performed not only in his native Azerbaijan but also in Turkey, England, Norway, Israel, Canada, Georgia, and other countries.

R. Ramazanov is currently experiencing a period of growth in his creativity, enriching our professional music art by creating new modern works.

Keywords: Rufat Ramazanov; symphonic works; individual style; musical language; modernity; national features

\section{Introduction}

For the first time, the article examines the symphonic work of Rufat Ramazanov, a middle-aged representative of the Azerbaijan School of Composition, a member of the Board of the Union of Composers, a member of the "Composers" section of the Professional Film Directors Guild of the Republic of Azerbaijan. As a researcher of the works of Rufat Ramazanov, I can say that the emergence of the characteristics of modern composer's work is one of the important and urgent tasks of modern Azerbaijani national musicology.

The study of the orchestral record of R. Ramazanov, one of the worthy representatives of the Azerbaijani school of modern composition, which directly reflects the search for style in the field of symphonic music, is one of the most important factors in solving the problem. In some works by Ramazanov, composed for symphony orchestra, orchestral writing, realized in unity with the whole complex of means of expression, is a unique indicator of composition, genre-style, individual interpretation of musical language systems, and most important stylistic features.

The works composed by Ramazanov for symphony orchestra can be considered as the result of the composer's many searches and, in a sense, as a general result. It should be noted that when the composer applied to the symphonic genre, he did not intend to create works with huge forms, he expressed the events and facts that were of interest to him and were in the centre of his attention.

\section{Purpose of the research}

The main purpose of appealing to the symphonic work of Rufat Ramazanov is to study the work of the composer, which is considered important in modern Azerbaijani music, and to reveal the stylistic features. The article examines the features of R. Ramazanov's writing style, various forms of movement of the melody, features of development, the basis of the national style, and compositional structure in his symphonic works. Our goal in the research process is to reveal the general creative 
face of the composer by analyzing several works belonging to the symphonic work of R. Ramazanov.

\section{Recent research and publications analysis}

Ramazanov's work is important in studying the development of the modern Azerbaijani school of composition. Some of the composer's works and features of writing techniques are briefly covered in the scientific research work of Azerbaijani musicologists. Some of Ramazanov's symphonic and chamber works have been studied in the scientific research works of A. Abasova and A. Ashumova on Azerbaijani music, and they form the scientific basis of the presented article.

\section{Main research material}

R. Ramazanov, who has a colourful creative palette, appealed to the symphonic genre, and in this field - as a talented artist with an individual set of lines, and such works of the composer can be considered worthy pearls in the history of Azerbaijani symphonic music. The manuscript scores obtained during the research were useful material for scientific research. The fate of the composer's symphonic works, their content and musical language, as well as their form, series resolution, and dramatic-dynamic interpretation, are extremely diverse and interesting. At the same time, we would like to emphasize that in each of the works it is possible to feel the personality-different style of the composer, who feels the nature of the genre in all its subtlety and tries to create important, meaningful examples in this genre.

Head of the Department of Theory of the Nizhny Novgorod State Conservatory named after M. N. Glinka, Chairman of the Dissertation Council at the Nizhny Novgorod Conservatory, Honored Art Worker of the Russian Federation V. N. Syrov noted: "The comprehension of style problems today proceeds in different directions. The most fruitful seems to be their development not in the bosom of individual disciplines (history, theory, aesthetics), but at their junction. There are two paths here: 1) from general concepts of creativity, personality psychology - to specific manifestations of CS and the analysis of the most striking samples, 2) from individual empirical observations - to the construction of universal concepts of style. Each has its advantages and costs: after all, the temptation of groundless abstraction is no less strong than wingless empiricism." (Syrov, 2015, p. 44).

Rufat Ramazanov is one of the talented figures of our time in the music culture of Azerbaijan. He stands out among modern Azerbaijani composers with his style. The composer, who lived through the period of perfection of his work, appealed to many genres and created beautiful works of art in the music culture of Azerbaijan. Along with new stylistic tendencies, Ramazanov, who has a special place among modern Azerbaijani composers, also experiences nationalism.

The musical language of the composer's works has not only adapted to modern times but also preserved its national identity. The following views on the features of Ramazanov's works are consistent: "In the variety of stylistic manifestations 
of contemporary musical art, the orientation towards simplification of the musical language within the framework of the individual-composer style is a stable stylistic trend, which is associated with a new vector of development of artistic and aesthetic standards of "the art of intonated meaning" and creative ideas about the tasks and functions of music as a form of culture and type of artistic practice" (Ovsyannikova-Trel, 2020, p. 227).

To date, Ramazanov has written symphonic poems "Hurufs", "Ballet Suite" for large symphony orchestra, "Fazlullah Naimi" symphonic poem, "Dedication to Gara Garayev" symphony, symphonic music for "Impression" string orchestra, mixed choir and large symphony. He wrote chamber works "For the Love of Freedom" for orchestra.

The "Ballet Suite" composed for a large symphony orchestra was one of the composer's most serious works and one of the first presentations of his unique symphonic thoughts. The work convincingly reveals the best aspects of the composer's symphonic talent.

The introductory part of the work is based on the general intonation of the suite. Its rhythmic sequence is given in a different atmosphere, born of the intonations of the main theme.
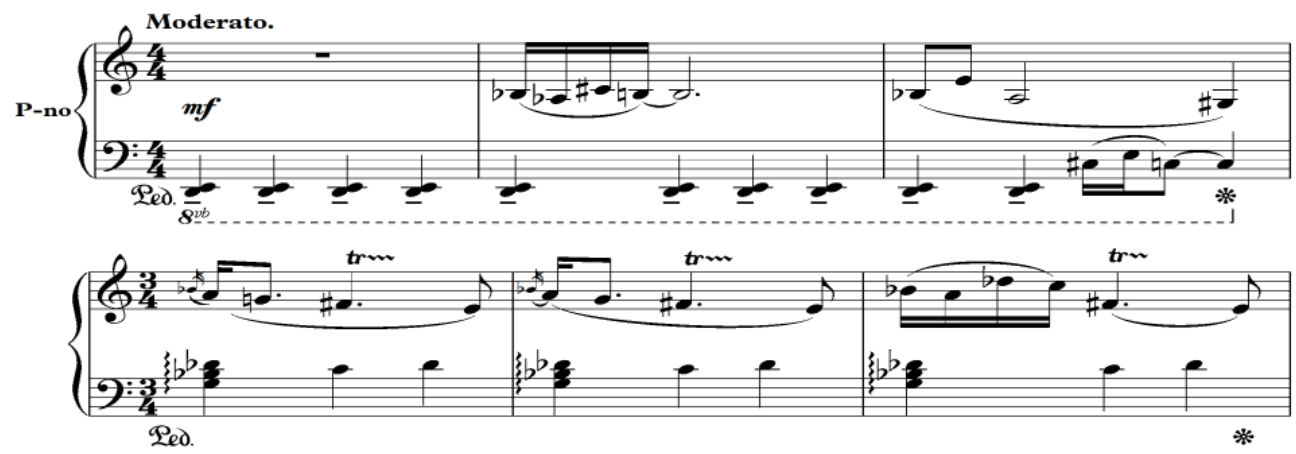

Example 1.

Here the example of melodic structure is written by the same intonationrhythmic means. The given music sample introduces the main theme of the suite. The composer solved the main theme of the dance sample on the content-image feature of the dance melody. It is a kind of folk-dance music widely developed for symphony orchestras. It is clear from the score that Ramazanov expanded the interpretation of the main theme based on the variability of some repetitive episodes. However, the main factor here is that the texture is filled with delicate ornaments and has a free rhythm. Also, the form of the work (simple three-part) is closely related to the development of the general content. From the first moments of the work, a characteristic feature of the young composer's writing style is revealed the composer intensifies the development of varied themes by creating an internal connection of small tunes, and the polyphony factor plays a significant role in this. 
"Alov Bayramı"

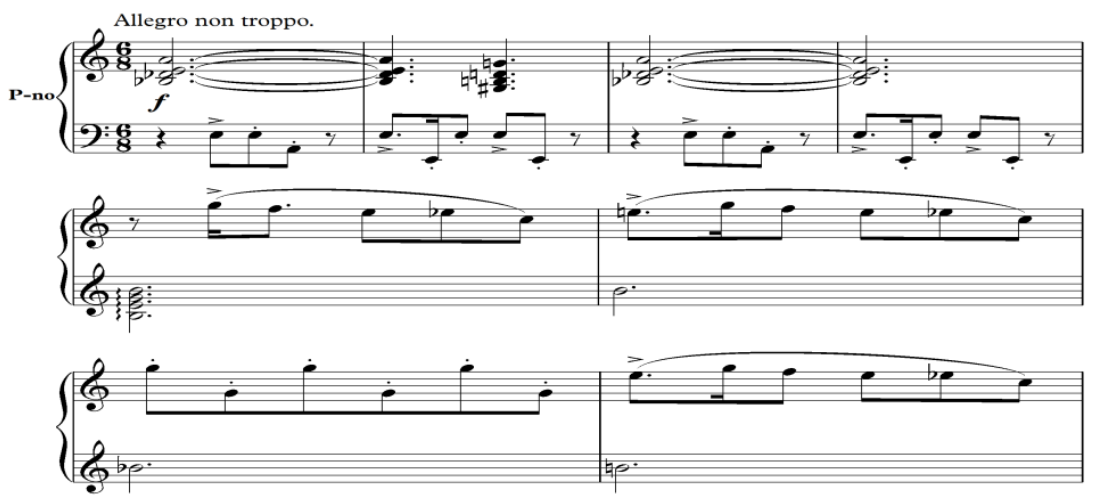

Example 2.

The orchestration of the main theme is based on the joint or alternate performance of different groups of musical instruments, which gives dynamics to the development of the theme.

Using the variety of timbre of the symphony orchestra in the work, the composer was able to create very valuable work. The work is full of deep choreographic elements.

\section{"Zərdüştün monoloqu"}

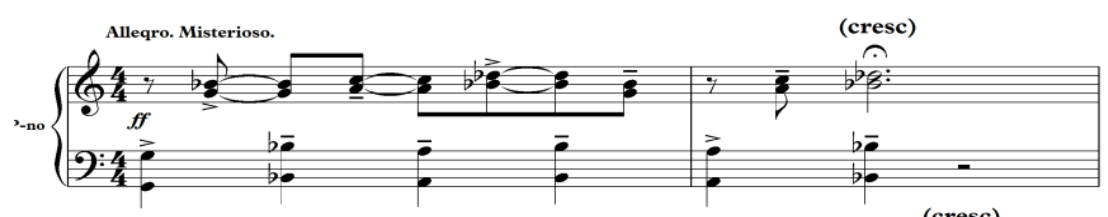

(cresc)

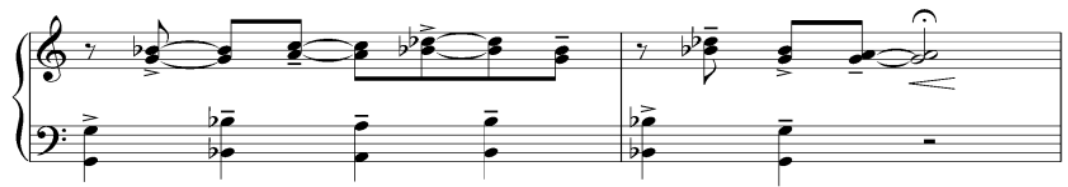

Example 3.

Based on the work, the composer can easily create a miniature of ballet in the pool, and this work becomes a very interesting event, a new and more beautiful example of music can be written in the pages of the history of Azerbaijani choreography.

As for the musical language of the work, the composer uses several colourful dance episodes, skillfully combining delicate ornaments and free metro rhythms in their future development. The predominance of rhythm in the composer's works is connected with this idea: "Thus, the rhythm factor occupies a significant place in the development of style. The rhythmic organization of music is especially closely related to its genre indicators" (Shvetsova, 2017, p. 7). 
Also, Ramazanov has a synthesis with a set of handwriting. In the Ballet Suite, composed of a large symphony orchestra, the change in tempo and general character of the movement is repeated, as if reminiscent of the sonata, the adagio, the scherzo, and the concise expression of the work within a single piece. Although there is no preprogrammed image-idea in the work, the development of the language of music in the opening of symphonic thinking acts as an equal component to the general dramatic evolution. Also, the texture in the work retains its unchanging position from beginning to end. The naming of the work "Ballet Suite" is primarily due to the mastery of the composer's ability to express choreographic music. Based on this suite, the author showed his first examples of choreographic music. The superiority of choreographic elements in the work is undeniable.

As can be seen, despite the small rhythmic changes in the work, the development of the whole musical line from the beginning to the end, the movement of music, and the culmination of the moment are based on choreographic elements, indicating the completeness of the image idea solution. The small episode of the introduction, which is completed at the end of the work, brings special exhaustion to the work and reminds of the revival of the first excitement of the musical image. In general, the melodic movement and figurative dramatic development in the work complete the line of development of the composer's musical language.

This work, which can be noted as proof of the originality of Ramazanov's musical language, is a charming example of modern composition, although it coincides with the composer's youth. The work was performed in 2001 by the Azerbaijan State Symphony Orchestra under the direction of the People's Artist of Azerbaijan and the USSR R. Abdullayev.

The symphonic poem "Fazlullah Naimi" is one of the masterpieces of Ramazanov's work. Written in 2001, this work is intended for a large symphony orchestra. The revival of the image of the Sufi scholar, poet, philosopher Fazlullah bin Abi Muhammad Naimi Tabrizi, the founder of the sect of Hurufism, in music required the young composer a serious approach to his work, perfect orchestral composition, and the ability to combine religious themes with modern music.

The work was performed in 2003 by the Azerbaijan State Symphony Orchestra under the direction of the People's Artist of Azerbaijan and the USSR R. Abdullayev.

One of the most interesting and at the same time new topics and ideas in the field of national music creation is religious music and its expression and solution within the modern concept. Religious music, with its imaginative expression, has been widely used in the works of Azerbaijani composers.

However, it should not be overlooked that in the works of our composers, religious music and appeals to religious themes are written in different senses. In general, the principle of appealing to religion in the composer's work is manifested in several different aspects: the first appeals to religious music in a particular work, i.e. the use of religious-mourning music in the form of quotations, the 2nd - in religious works intonations with intonations of certain mugham sections. For example the use of the intonation feature of the "Zamin-Khara" section of the "Bayati-Gajar" mugham, the revival of the idea-image feature in the musical language using the 3rd emotional-psychological aspect. The third principle of use 
mentioned above is clearly expressed in Ramazanov's symphonic poem "Fazlullah Naimi”.

Based on the musical material of the poem, the emotionally rich and expressive power of human life, lyrical and enlightening thoughts in the opening of the dramatic line of the image is given in the mainline, where the composer used the orchestral timbre with special care in the charm of musical language. The sincerity of the feelings expressed in the music, the richness of the concept used, the subtle approach in choosing the timbre of the work, the completeness of the whole composition - all this determines the aesthetic musical merits of the composer R. Ramazanov in the symphonic poem "Fazlullah Naimi”.

In the orchestra, which introduces moderato, Pomposo tempo, and $4 \backslash 4$ rhythms, the musical material demonstrates the cells of the sufficiently heavy and at the same time as convincing sounds of the embodiment of lyrical feelings in the work. The orchestra uses the lowest timbres (Violoncelli, Contrabassi; Clarinetto Basso, Fagotti, Contrafagotti; Tuba, Timpani), and the theme itself, or rather the first thematic element, is performed by these groups. This choice of orchestral colours is striking and demonstrates the composer/s writing style. While the main theme is fully developed in the orchestra, the composer presents a very interesting musical material performed by strings and solo flute. Accompanied by strings (Viole) and harp (Arpe), the solo flute sounds very soft and a little sad, as a lyrical continuation of a restrained musical material. Wooden wind instruments, which continue the musical material in threes, give some vitality to the development of the subject.

Adagio, the middle part of the work begins with sostenuto tempo. Although the orchestra performs only musical material for six chants on winds, harps, and strings, the main theme is performed on winds. The theme, which is then performed by these groups with a modest, restrained character, creates an unusual atmosphere in the orchestra's timbre. The orchestra has a very subtle dialogue effect. The increasing dynamics lead to the full development of the subject (f), and finally, the melodic movement calms down a bit, reaching the climax (dim.). The musical texture of the strings is given in a precise chord line, which makes the theme of the wind instruments even more pronounced.

A new dynamically developing phase of the poem - Allegro, Sforzo coincides with the section. Dynamic excitement is combined with the instability of the main theme and the increasing tension of the musical line. It is based on laconic impulsive motives that coincide in the line of great dynamic rise and coverage. Here, the breadth of the melodic range, the "scattering" of the orchestral texture, indicates the dynamics of sharp intonations.

The main intonation centre of the subject is the motif of the first bar with an active rhythmic figure. All the further development of this section is given in the development of this small tune core in the orchestra in different intonation colours.

From the part of Ad Libitum, the composer entrusts a completely arbitrary orchestra. From this part, a magnificent batch of wind instruments and strings is played. The general dramatic line of the glissando musical material performed by the nine-stringed harp is given an unusual timbre on the one hand and grandeur on the other. 


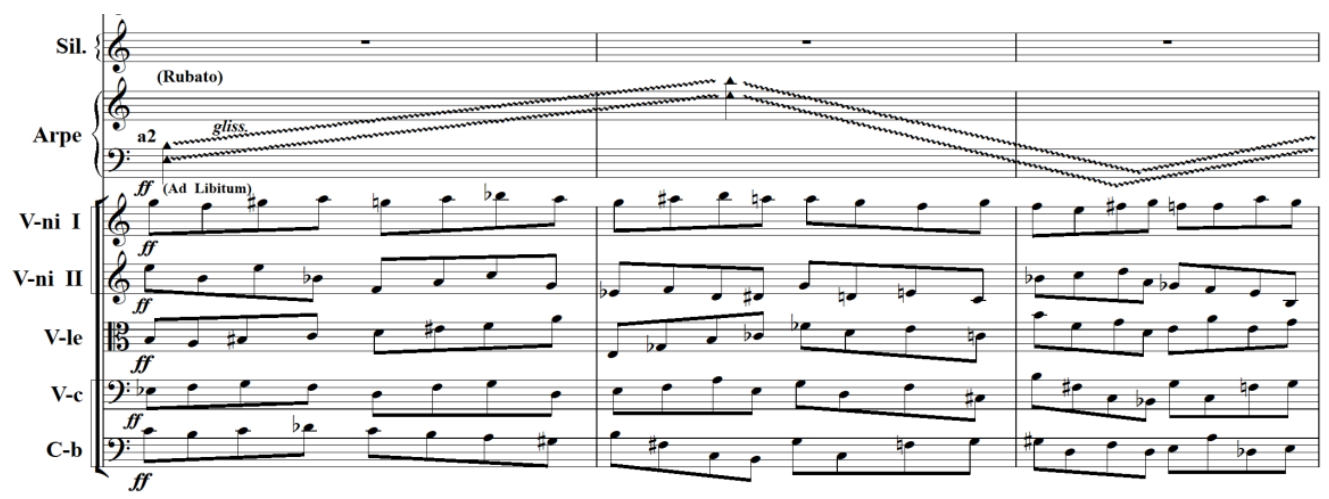

Example 4.

Musical material brings to life the image that expresses the highest ideal of human personality. The turmoil in Allegro's early cells continues to grow amid growing excitement. The theme is simple, but also very suitable for a complex development line. The harmonic writing in the work alternates with dissonant sounds, and has a more affirmative function, especially at the culmination of the musical material.

The analysis of the score confirms that the main leading line of stringed instruments in the poem creates a vivid example of the method of mutual sounding, connected with wind instruments.

The symphonic poem "Fazlullah Naimi" was highly praised in the "Symphonic Music" nomination, and for this work, the composer was awarded the Azerbaijan Youth Prize in 2003.

The symphony "Dedication to Gara Garayev" can be considered one of the most valuable works of art written by Ramazanov in 2006. The symphony was written for the full staff of the Grand Symphony Orchestra. The work was performed on November 12, 2009, on the first day of the International Festival dedicated to the 75th anniversary of the Union of Composers of Azerbaijan, and was met with great sympathy.

The author said: "In this symphonic poem I tried to create a hymn to the creative image of Gara Garayev and the expression of his philosophical views in the language of music." It should be noted that immediately after the premiere of the symphony, V. V. Medushevsky, Professor of Music Theory at the Moscow State Conservatory, Honoured Artist of Russia, praised the work and expressed a very positive opinion on it.

As it is already known, the appeal to the works of well-known personalities, the revival of their worlds of images and ideas in music, the creation of a kind of selfportraits of geniuses are common in Ramazanov's work.

Gara Garayev's work is the cultural heritage of the Azerbaijani people. Various paintings and music were composed, reflecting the image and inaccessible creativity of the famous composer. The first attempt to get acquainted with the symphony is the fact that this work contrasts with the composer's other first symphonic works and the freedom of the author's set and orchestral writing. Ramazanov fundamentally renews the language of music in the symphony and works quite confidently and convincingly within his style. In Ramazanov's portrait in the symphony "Dedication 
to Gara Garayev", the outstanding artist is portrayed as a philosopher and thinker. The main dramatic line of the symphony is dominated by tragedy. The tragedy in the work is also given as an embodiment of the images and inner world of Gara Garayev's works. The simple composition of the work is fascinating. Every stroke and figure in the orchestral writing in the work is appropriate and harmonious. The composer did not use any artistic methods in the image embodiment of the musical language and does not distract the listener's attention from the main theme - the image of Gara Garayev.

The symphony opens with the performance of the instruments Contrabassi and Gr. Cassa (SF) and talks about the general atmosphere of the whole symphony. Moderato, Tragico tempo, and 4/4 rhythm, the composer recreates the weight of the image of Gara Garayev from the first bars. Along with the twenty cells, the double bass is played in the form of a dialogue in the background of the organ point given in the other strings that are then connected to it. The transfer of percussion instruments to this background is an indication of the unusual tension.

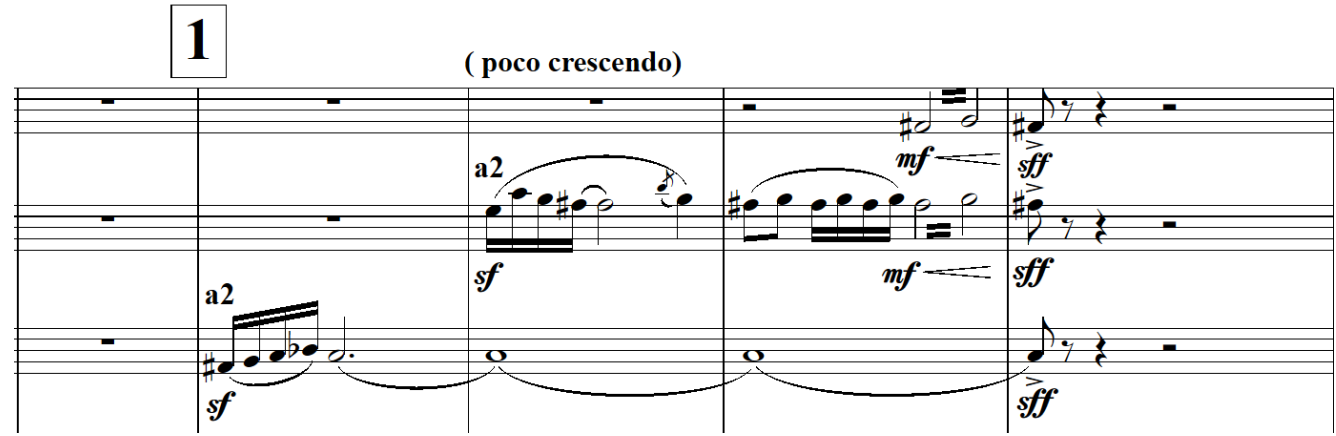

Example 5 .

The solo cello performance (sff) is recorded in the symphony as the embodiment of the image of Gara Garayev. The solo performance, which lasts for ten verses, is distinguished by the philosophical content of the musical character. The occasional solo performance of the percussion part was deliberately conceived by the composer. Here, the composer emphasizes two areas of the musical image in the work - restrained-philosophical and lyrical-tragic.

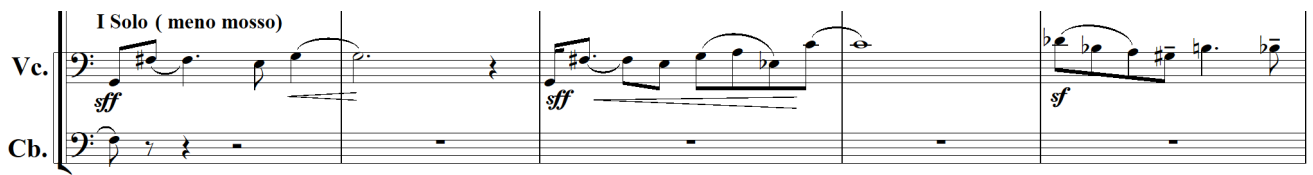

Example 6.

Adagio,Sostenuto (Lento) (3/4) begins a new stage in the development of the musical material of the work. Against the background of the flute's performance, the work "Second clusters" in strings prepares for new dramatic development. 
This section immediately takes you to Moderato, Tragico. (Misterioso). The initial tragic mood at the beginning of the work is given to the future development of the musical material based on the intonations of the "Zamin-Khara" section of "Bayati-Gajar" in this orchestra.

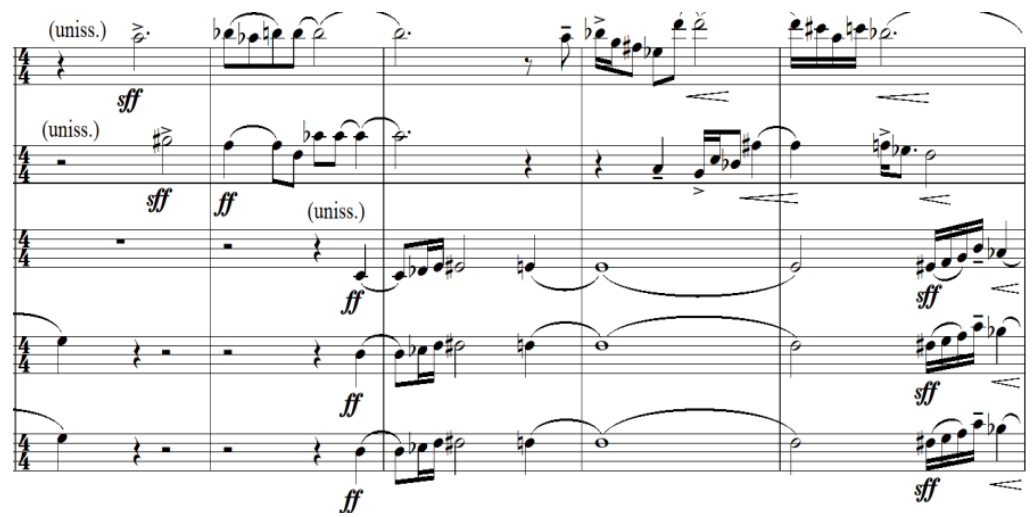

Example 7.

The given example is the main dramatic moment of the work as the middle part. As it is known from the music, the melodic pattern based on the lyrical-tragic image on the complex textured performance of the strings expresses itself in a very bright way. In the joint performance of the orchestra, he emphasizes the performance of strings as a kind of soloist, and at the same time performs the main function of the lyrical-tragic image that resonates within the orchestra. The preservation of the rhythm in the performance of the trombone and Tuba in the orchestra during the sound of the middle part was a sign of a continuous feeling of a kind of rhythmic pulse. There are interesting dichotomies in orchestration, which can be found in the timbre of the theme. In completing the middle part, its alternation with a small closing episode attracted attention.

The tutti in the orchestra - Allegro, misterioso - is the highest developmental solution of musical material as a part of the development of the work. Using the richness of timbre, the composer was able to achieve the peak of his inner feelings, turbulent life, and creativity in the orchestral sounding of Gara Garayev's image portrayed in the musical material.

The sound of a solo cello signals the culmination of the work. As the main theme, almost unchanged, only a small number of rhythmic strokes, with the addition of glissando, sound again in the solo performance of the cello. Here the original style of performance, texture structure, and orchestration technique are repeated as before. However, the composer adds timpani to the music material as a novelty in response to the performance of a solo cello. It should be noted that although it is difficult to adapt the cello and the timpani in terms of timbre in the form of questions and answers (the timpani instrument is considered to be less flexible in terms of intonation), the composer was able to achieve harmony within the orchestra.

In the performance of strings, the addition of triols and organ points in Contrabass further dynamized the development of the melodic line. Form structure of the work: 
$A B A A A B$ - processing - $A B A A$ exists as $A b$, which is subordinate to the form of rondo sonata. However, the composer creates a kind of light theme function by ensuring that the main theme, such as the reflection of the individual images in the development of musical material, transcends the boundaries of form several times inside the work. In the harmonic language of the symphony, the frequent sounding of various dissonance chord combinations, the widespread use of sonorous techniques, and modality are the main lines. Note that. The use of sonorous techniques is especially used in the presentation of music based on the intonations of the "Zamin-Khara" section of "Bayati-Gajar".

In general, the composer made extensive use of the dramatic basis of the musical material in the symphony "Dedication to Gara Garayev" - tempo, timbre, dynamics, harmony, texture - which, in turn, indicates that Ramazanov felt and wrote music with his heart.

The laconic intonation of the symphony is in harmony with the inner world of the famous composer Gara Garayev, who is distinguished by his inner restraint. The orchestral record presents the creative potential of a huge musical material divided into plastic motifs performed by a group of complementary instruments.

Describing the image of Gara Garayev in a generalized image interpretation, the composer was able to revive the inner views and feelings of a prominent figure in his work with infinite respect and love.

\section{Conclusions}

Thus, as a result, it can be said that the composer's works on symphonic creativity are very interesting. we observe the opposite in our searches.

Rufat Ramazanov's work is multifaceted and diverse in terms of modern professional composer's thinking, as well as the interpretation of the solution of the genre and image-idea. The composer, who is always in search of creativity in our time, attracts attention with his unique stylistic features, the embodiment of the language of music, colourful creative thinking, and imagination. The composer, who has a modern way of thinking, always reflects the current problems of our time and universal themes in his works.

The Head of the Department of Theory of the Nizhny Novgorod State Conservatory named after M. N. Glinka, the Chairman of the Dissertation Council at the Nizhny Novgorod Conservatory, the Honored Art Worker of the Russian Federation V. N. Syrov: "The artist's interest can be directed at comprehending the socio-ethical meaning of phenomena, while music is extremely close to the life of a person and society, conveying it in conflicts and dramatic collisions, but can rush into the infinity of the ideal, avoiding the prose of life, topicality, direct expression of the social, acute psychological, on the one hand, goes along the line of deepening the spiritual and ethical content, on the other, - enjoys the game, plunges into a certain primordial nature of the elemental forces of nature, carrying a transpersonal meaning " (Syrov, 2015, p. 47).

Each new symphonic work means a new stage in Ramazanov's work, deep mastery of modern artistic and aesthetic means, national culture. The lexicon of orchestral writing in his symphonic works is modern and unusual, based on national roots. Rufat 
Ramazanov's symphonic works express the high ethical ideal of deep philosophical thoughts, the complex inner world of human personality, spiritual shades. Each of the composer's works demonstrates the creative experience, comprehensive knowledge, and skills he has accumulated over the years.

\section{References}

Abasova, A. (2004). Genc Bestekarin Neimiye Muracieti [Young Composer's Appeal to Naimi]. In Problems of Research of National Music (Vol. 5, pp. 352-360). Adiloqlu [in Azerbaijani].

Abasova, A. (2010). Azerbaycan Bestekarlarinin Birhisseli Simfonik Eserlerinin Janr ve Uslub Chususiyyetləri [Genre and Stylistic Features of One-Part Symphonic Works of Azerbaijani Composers]. Elm ve tehsil [in Azerbaijani].

Ashumova, A. (Comp.). (2013). Organ v Sostave Ansamblevykh Form $v$ Tvorchestve Azerbaidzhanskikh Kompozitorov [Organ as Part of Ensemble Forms in the Works of Azerbaijani Composers]. Baku Music Academy named after U. Hajibeyli [in Russian].

Ashumova, A. (Comp.). (2015). Ideino-Obraznoe Soderzhanie i Osobennosti Traktovki Simfonii dlya Khora Mal'chikov i Organa Rufata Ramazanova [Ideological-Figurative Content and Peculiarities of the Interpretation of the Symphony for Boys Choir and Organ by Rufat Ramazanov]. Baku Music Academy named after U. Hajibeyli [in Russian].

Babayev, E. (1998). Shifahi Eneneli Azerbaycan Musiqisinde Intonasiya Problemleri [Problems of Intonation in Traditional Azerbaijani Music]. Elm [in Azerbaijani].

Bagirov, N. (1981). Muasir Harmoniyaya dair Bezi Akkordlarin Azerbaycan Musiqisinde Ishledilmesi [Use of Some Chords on Modern Harmony in Azerbaijani Music]. Maarif [in Azerbaijani].

Bagirov, N. (1989). Azerbaycan Musiqisinin Bezi Xususiyyetleri [Some Features of Azerbaijani Music]. Maarif [in Azerbaijani].

Dadashzade, Z. (1999). Simfoniyanin Fezasi. 1970-80-ci iller. Azerbaycan Simfoniyasi: Esas Temayuller [The Space of the Symphony. 1970s-80s. Azerbaijani Symphony: Main Trends]. Elm [in Azerbaijani].

Eliyeva, F. (1996). Azerbaycan Musiqisinde Uslub Axtarishlari [Stylistic Research in Azerbaijani Music]. Elm [in Azerbaijani].

Kohoutek, C. (1976). Tekhnika Kompozitsii v Muzyke XX veka [Technique of Composition in Music of the XX Century] (K. N. Ivanov, Trans.). Muzyka [in Russian].

Mazel, L. (1952). O Melodii [About the Melody]. Muzgiz [in Russian].

Mazel, L. (1979). Voprosy Analiza Muzyki [Music Analysis Issues]. Muzyka [in Russian].

Mazel, L. (1983). O Prirode i Sredstvakh Muzyki: Teoreticheskii Ocherk [On the Nature and Means of Music: A Theoretical Essay]. Muzyka [in Russian].

Mazel, L. (1986). Stroenie Muzykal'nykh Proizvedenii [The Strukture of Musical Works] (3rd ed.). Muzyka [in Russian].

Ovsyannikova-Trel, A. (2020, November 27-28). "Novaya Prostota" v Sovremennom Muzykal'nom Iskusstve (Ponyatiino-Terminologicheskii Aspekt) ["New Simplicity" in Contemporary Musical Art (Conceptual and Terminological Aspect)]. In Cultural Studies and Art Criticism: Things in Common and Development Prospects, International Scientific and Practical Conference (pp. 227-230). Baltija Publishing. https://doi.org/10.30525/978-9934-26-004-9-128 [in Russian]. 
Shvetsova, O. (2017). Vospitanie Muzykal'nogo Slukha: Stilisticheskii Aspekt [Education of Musical Hearing: Stylistic Aspect]. Chelovek i Kul'tura [Man and Culture], 4, 1-12. https://doi. org/10.25136/2409-8744.2017.4.23755 [in Russian].

Syrov, V. (2015). Kompozitorskii Stil' Kak Dinamicheskaya Sistema [A Composer Style as a Dynamic System]. Musiqi Dünyası [World of Music], 1(62), 44-53 [in Russian].

\section{СИМФОНІЧНА ТВОРЧІСТЬ РУФАТА РАМАЗАНОВА}

\section{Мехпара Рзаєва}

доктор філософських наук з мистецтвознавства, старший науковий співробітник; ORCID: 0000-0002-0962-5416; e-mail: mexpara.rzayeva@mail.ru Бакинська музична академія імені Узеїра Гаджибейлі, Баку, Азербайджан

\section{Анотація}

у статті проаналізовані твори, пов'язані з симфонічною творчістю Руфата Рамазанова - представника сучасної азербайджанської композиторської школи. Також розглядаються симфонічні твори Р. Рамазанова на тлі розвитку азербайджанської музичної культури і з точки зору жанрового розмаїття. Крім того, в статті висвітлено особливості музики і гармонійної мови в симфонічних творах композитора, засоби використання оркестровки. Наголошується на унікальних стилістичних особливостях симфонічних творів Руфата Рамазанова, їх зв'язку з народною творчістю і прагненням до модернізації в рамках традицій.

Мета дослідження - аналіз окремих симфонічних творів Руфата Рамазанова і вивчення індивідуальних стилістичних особливостей композитора. Основними штрихами стали поява характерних рис симфонічної творчості композитора і відкриття його зв'язку з сучасною азербайджанською музичною культурою.

Методологія дослідження ґрунтується на музично-аналітичному, теоретичному і історичному аналізі. Було відзначено, що в процесі розвитку творчість композитора зазнала стилістичних змін, а сучасні технічні засоби проявили себе унікальним чином. Водночас методологічну основу статті складають засновані на науково-теоретичних засадах дослідження азербайджанських і закордонних музикознавців. В основі дослідження лежить залучення до детального наукового дослідження цінних симфонічних творів Р. Рамазанова, гідного представника сучасного покоління азербайджанських композиторів, що не зазнали науково-теоретичного аналізу.

Наукова новизна дослідження полягає в тому, що вперше в якості спеціальної дослідницької роботи обрано симфонічні твори Р. Рамазанова і вивчено загальні творчі особливості. У представленій статті вперше проводиться науковий аналіз симфонічних творів Р. Рамазанова, важливих в його творчості, але дотепер не вивчених.

Висновки. Всебічний аналіз симфонічних творів Р. Рамазанова в представленій статті дозволяє зробити важливі висновки про особливості творчого стилю композитора. Зазначено, що багатство і глибокий зміст музичної мови яскравих і індивідуальних симфонічних творів, створених композитором, що відрізняються самобутнім творчим 
стилем, в різні роки його творчого життя мають важливе значення в національній музиці.

Відзначено, що наполегливість і серйозність композитора до себе відчувається і в характері його творів. Слід зазначити, що твори Рамазанова успішно виконувались не тільки в його рідному Азербайджані, але і в Туреччині, Норвегії, Ізраїлі, Канаді, Грузії та інших країнах. Р. Рамазанов нині переживає період зростання своєї творчості, збагачуючи професійне музичне мистецтво створенням нових сучасних творів.

Ключові слова: Руфат Рамазанов; симфонічні твори; індивідуальний стиль; музична мова; сучасність; національні особливості

\section{СИМФОНИЧЕСКОЕ ТВОРЧЕСТВО РУФАТА РАМАЗАНОВА}

\section{Мехпара Рзаева}

доктор философских наук по искусствоведению, старший научный сотрудник;

ORCID: 0000-0002-0962-5416; e-mail: mexpara.rzayeva@mail.ru

Бакинская музыкальная академия имени Узеира Гаджибейли, Баку, Азербайджан

\section{Аннотация}

В статье проанализированы произведения, связанные с симфоническим творчеством Руфата Рамазанова - представителя современной азербайджанской композиторской школы. Также рассматриваются симфонические произведения Р. Рамазанова на фоне развития азербайджанской музыкальной культуры и с точки зрения жанрового разнообразия. Кроме того, в статье освещены особенности музыки и гармонического языка в симфонических произведениях композитора, приемы использования оркестровки. Отмечены уникальные стилистические особенности симфонических произведений Руфата Рамазанова, их связь с народным творчеством и стремление к модернизации в рамках традиций.

Цель исследования - анализ отдельных симфонических произведений Руфата Рамазанова и изучение индивидуальных стилистических особенностей композитора. Основными штрихами стали появление характерных черт симфонического творчества композитора и открытие его связи с современной азербайджанской музыкальной культурой.

Методология исследования основана на музыкально-аналитическом, теоретическом и историческоманализе. Было отмечено, что впроцессеразвития творчество композитора претерпело стилистические изменения, а современные технические приемы проявили себя уникальным образом. Вместе с тем методологическую основу статьи составляют основанные на научно-теоретических принципах исследования азербайджанских и зарубежных музыковедов. В основе исследования лежит привлечение к детальному научному исследованию ценных симфонических произведений Р. Рамазанова, достойного представителя современного поколения азербайджанских композиторов, не подвергшихся научно-теоретическому анализу.

Научная новизна исследования заключается в том, что впервые в качестве специальной исследовательской работы выбраны симфонические произведения 
Р. Рамазанова и изучены общие творческие особенности. В представленной статье впервые проводится научный анализ симфонических произведений Р. Рамазанова, важных в его творчестве, но до сих пор не изученных.

Выводы. Всесторонний анализ симфонических произведений Р. Рамазанова в представленной статьепозволяетсделать важныевыводы об особенностяхтворческого стиля композитора. Указано, что богатство и глубокое содержание музыкального языка ярких и индивидуальных симфонических произведений, созданных композитором, отличающихся самобытным творческим стилем, в разные годы его творческой жизни имеют важное значение в национальной музыке.

Замечено, что настойчивость и серьезность композитора к себе чувствуется и в характере его произведений. Следует отметить, что произведения Рамазанова успешно исполнялись не только в его родном Азербайджане, но и в Турции, Норвегии, Израиле, Канаде, Грузии и других странах. Р. Рамазанов в настоящее время переживает период роста своего творчества, обогащая профессиональное музыкальное искусство созданием новых современных произведений.

Ключевые слова: Руфат Рамазанов; симфонические произведения; индивидуальный стиль; музыкальный язык; современность; национальные особенности 